\title{
PRAGMATICS APPROACH IN TEACHING MAHARAH KALAM AT PONDOK MODERN DARUL HIKMAH TULUNGAGUNG
}

\author{
Mohamad Jazeri ${ }^{1}$ \\ 1(IAIN Tulungagung/m-jazeri2018@iain-tulungagung.ac.id) \\ Kojin $^{2}$ \\ 2(IAIN Tulungagung/ jeryadiba2016@gmail.com) \\ Dwi Astuti Wahyu Nurhayati ${ }^{3}$ \\ 33(IAIN Tulungagung/dwiastuti507@gmail.com)
}

\begin{abstract}
Speaking proficiency, maharah kalam, is one of the Arabic teaching goals at Pondok Modern Darul Hikmah Tulungagung. Speaking skill will be better mastered by the understanding of language usage in the daily communication context. Therefore, Pragmatics approach is fruitfully employed in teaching speaking skill. This study aims at describing the Pragmatics approach in teaching speaking skill at Pondok Modern Darul Hikmah Tulungagung. This study belonged to queasy experiment. Data were collected through doing participation-observation, interview, and test. The result of data analysis revealed that Pragmatics approach in teaching Arabic speaking skill in Pondok Modern Darul Hikmah was reflected in the instructional design. This approach was implemented through three programs, namely dialogue (al-hiwar), pattern practice (tathbiq al-namudzaj), and oral practice (tarkib al-syafawi). In addition, there was a significant difference result of pre-test and post-test. It was assumed as an effect of applying pragmatics approach in teaching maharah kalam at Pondok Modern Darul Hikmah Tulungagung.
\end{abstract}

Keywords:

Pragmatics, Speaking Skill, Dialogue, Public Speaking

DOI: $10.19105 /$ ojbs.v12i2.1949

\section{A. Introduction}

The aim of teaching maharah kalam is a communicative ability to use Arabic based on the usage of social contexts. These social contexts mean that a speaker could understand the hearer, speech act and the context of act. Unfortunately, most learners (santri) who learn Arabic for many years, could not use it based on its context. Why did it happen? Because they learn Arabic structure (the tarkib), they do not use it any contexts of real life. The teachers in this case (ustadz) teach Arabic based on the formal system such as part of speech and its syntax, they do not teach 
it based on the language function in real communication. The teaching Arabic aims to master the language system, it does not focus on the ability to use it by considering the speaker and the hearer.

In order that the leaners of Arabic could master language usage based on the context usage and function in real communication, it is necessary to use a new approach in teaching Arabic, that is pragmatics approach. Mostly the pragmatics approach is focused on language usage in society and the speaker as part of the language society. Using language should consider the utterance context, speech act, the interlocutor, the tact maxim and implicature based on the communication context as the focus of teaching language using pragmatics approach. This focus of the research is different from other approaches which concern to language and separated from the context. Mostly, Pragmatics approach is focused on the language usage in society and the speaker as part of language society. ${ }^{1}$

In teaching L2, actually, the pragmatics aspect has become an important part of it. However, in fact, pragmatics has not become an important part in teaching L2. In this case, there were any gaps between the theory of $\mathrm{L} 2$ acquisition and teaching practice in $\mathrm{L} 2$.

\footnotetext{
${ }^{1}$ K. Rajagopalan, "Social Aspects of Pragmatics," Encyclopedia of Language \& Linguistics, 2006, 434-40, https://doi.org/10.1016/B0-08-0448542/00316-3.
}

Theoretically, communicative competence becomes the important part of the L2 acquisition, so the development of curriculum in teaching L2 in this last decades, the pragmatics component has become the important part, even pragmatics was adopted as a new approach in teaching L2. ${ }^{2}$

All practitioners of learning language agreed that the role of pragmatics in teaching $\mathrm{L} 2$ becomes more important. In order to achieve those goals, it is necessary to conduct this pragmatics research in teaching the L2 classroom. Some of the researches have found many differences in $L 1$ and L2 acquisition. These differences include the difference of speech act, choice of semantics formula or pattern, and the content of semantics' formula. The input and the source of learning, the understanding of cross-culture, and pragmatics cross-language so far this approach has contributed very much in developing learning materials of $L 2$. The framework of speech act theory can be used by the learners in order to help the teachers and learners in conducting interactions in L2. In this case, the process teaching and learning was focused on learners (learners-centered method), it can be appropriate to contribute the success of teaching L2 using pragmatics approach. ${ }^{3}$

\footnotetext{
2 Gabriele Kasper, "Introduction: Interlanguage Pragmatics in SLA," Studies in Second Language Acquisition 18, no. 02 (June 1996): 145-48, https://doi.org/10.1017/S0272263100014856.

3 Bardovi-Harlig Kathleen, "Pragmatics and Language Teaching: Bringing Pragmatic and
} 
So far, it is proved that the pragmatics approach could improve the interaction competence in daily activity using second language (L2). ${ }^{4}$ In teaching reading story, pragmatics approach could invite the learners to rearrange the story which is written by the writer. The learners are involved in creating the story by asking them to complete the text or fill in the blanks of the text. For example, in a dialogue, the part of explicit of the character's utterance are omitted in order to examine the readers' comprehension about the unspoken utterances in some sentences. Hence, the reader's understanding does not depend on the text but all the contexts. In this case, it happens a collaboration between the writer and the readers by filling the blanks of the text. ${ }^{5}$

The learners of L2 often face the pragmatic problems such as uttering command, invitation, and complaints. In this case, the teachers are hoped that they could teach pragmatics aspects in using language and give examples of using spoken language in real communication. The teaching materials are designed in order to improve the learners' awareness about the norms of communication which is owned by a true speaker. The result of evaluation

Pedagogy Together," Pragmatics and Language Learning 7 (1996): 21-39.

${ }^{4} \mathrm{~B}$ Mallikarjun et al., "Communicative Language Teaching - A Comprehensive Approach to English Language Teaching" 12, no. 2 (2012): 249-65.

5 J. L. Mey, "Pragmatics of Reading," Encyclopedia of Language \& Linguistics, 2006, 32-38, https://doi.org/10.1016/b0-08-0448542/00387-4. towards the pragmatics approach shows that the pragmatics competence in uttering asking becomes better. The learners competence to utter asking become better, it tends closely to the true speaker's utterances. So, the teaching is focused on the development pragmatics competence and it shows the positive result. $^{6}$

Based on the explanation above, this research aims to describe the pragmatic approach in teaching maharah kalam at Pondok Modern Darul Hikmah Tulungagung. It is different from the previous research, this research is focused on the techniques of teaching maharah kalam which are implemented at pondok Modern Darul Hikmah Tulungagung. The research is aimed to describe what is the pragmatic approach in teaching maharah kalam at Pondok Modern Darul Hikmah Tulungagung, to explain how is the implementation of a pragmatic approach in teaching maharah kalam at Pondok Modern Darul Hikmah Tulungagung, and how the evaluation of a pragmatic approach in teaching maharah kalam at Pondok Modern Darul Hikmah Tulungagung.

\section{B. Method}

This research is a qualitative research with case study design. This research was conducted at Pondok modern Darul Hikmah Tulungagung where Arabic and English were the

\footnotetext{
6 E. Crandall, "Evaluating Pragmatics-Focused Materials," ELT Journal 58, no. 1 (January 1, 2004): 38-49, https://doi.org/10.1093/elt/58.1.38.
} 
official languages. The data were collected by using observation technique, interview, and test.

The qualitative data were analyzed using flow chart, adapted from Miles and Huberman, that is an interactive analysis which consists of collecting data, data reduction, data presentation, data verification, and the final result. $^{7}$ Whereas the quantitative data, that is the mean of pre-test score and post-test were analyzed using statistic in order to find the difference from the result of both tests. The difference was counted by reducing the post-test score $\left(0^{2}\right)$ with the pre-test score $\left(0^{1}\right)$. The difference score was assumed that as the result of teaching language using pragmatics score. ${ }^{8}$

\section{Results}

Based on the result of data analysis, it was known that pragmatics approach in teaching maharah kalam at pondok Modern Darul Hikmah Tulungagung was manifested into lesson plan (l'dad). The teaching was implemented in three teaching activities in maharah kalam. First, teaching maharah kalam used dialogue technique (al-hiwar). Second, teaching maharah kalam used technique of patterned practice (tathbiq al-namudzaj). Third, teaching maharah kalam used technique

\footnotetext{
${ }^{7}$ Matthew B. Miles and A. Michael Huberman, Qualitative Data Analysis, 3rd ed. (London: SAGE, 2014).

${ }^{8}$ Suharsimi Arikunto, Prosedur Penelitian: Suatu Pendekatan Praktik (Jakarta: Rineka Cipta, 2008).
}

of spoken composition (tarkib alsyafawi). This research also found that pragmatics approach in teaching maharah kalam at Pondok Modern Darul Hikmah could improve the speaking skill for Arabic learners.

\section{Pragmatics Approach}

Pragmatics approach in teaching maharah kalam at Pondok Modern Darul Hikmah could be seen and observed from the lesson plan (i'dad) which was composed by the ustadz. The pragmatics aspects which were taught including deixis, speech act, politeness and implicature of conversation. ThTis findings could be seen from the interview's result as follows:

"Teaching maharah kalam, in this case, tends to focus on the function of Arabic used in daily communication. For example, deixis, speech act of locution, questioning, asking, requesting, commanding and thanking. There were also the politeness language usage, the conversation of implicature, the use of sentences (word) based on the context."

\section{Implementation of Pragmatics Approach in Teaching Maharah Kalam in Pondok Modern Darul Hikmah Tulungagung}

Teaching maharah kalam using pragmatics approach at Pondok Modern Darul Hikmah Tulungagung could be implemented into three

\footnotetext{
${ }^{9}$ Annasrullah, A Coordinator of Arabic Teaching, Direct Interview, October 6, 2018.
} 
types of teaching and learning, those are dialogue (al-hiwar), patterned practice (tathbiq al-namudzaj), and spoken composition (tarkib alsyafawi).The following is the interview's result with one of learner of maharah kalam.

"To teach maharah kalam at this pondok, there were three mutual support programs. Every Sunday morning after exercising, the dialogue practice was held (alhiwar). Every after praying Isya and Subuh the communication patterned was guided by muddabir. Every Thursday night, the speech practice of using Arabic was held. Those three activities were supposed that it could be manifested the pondok icon or superior program, those were communication using Arabic and English. ${ }^{10 "}$

\section{Dialogue (al-hiwar is a} practice of speaking skill using Arabic in pairs. The dialogue was held every Sunday morning after exercising. After they have exercised and gymnastic, all santri/ students were asked to meet up or gather in the field and practiced it face to face. Through a loudspeaker, ustadz gave examples of the dialogue which must be imitated by all santri/ students.

Patterned practice (tathbiq alnamudzaj) is a practice of speaking skill using Arabic based on the pragmatics function with the guidance of pattern dialogues which were given

${ }^{10}$ M. Faiq, A Teacher of Arabic, Direct Interview, October 6, 2018. the examples in the textbook. Patterned practice aimed to make the santri/ students were able to communicate using Arabic based its function in social life, like asking, commanding, apologizing, thanking and etc.

In conducting spoken composition (tarkib al-syafawi) santri/ students are asked to create speech text and in turn, they are asked to deliver a speech in front of their friends. The speech program is conducted every Thursday night after praying Isya'. In order to strengthen their speaking ability in using Arabic, every the end of the semester, the Pondok always hold Arabic speech competition.

\section{Evaluation of Pragmatics Approach in Teaching Maharah Kalam at Pondok Modern Darul Hikmah Tulungagung}

Teaching evaluation of maharah kalam using pragmatics approach at Pondok Modern Darul Hikmah Tulungagung was conducted through pre-test and post-test. Based on the result of both tests, it was found that the mean of pre-test score was 60.2 and the mean of post-test was 81.3. The range between pre-test score and post-test score could be assumed that it showed the result of the implementation of pragmatic approach. Thus, it can be concluded that pragmatics approach could improve the speaking ability in 
teaching maharah kalam at Pondok Modern Darul Hikmah Tulungaung.

Based on the result above, shortly, it is found that the pragmatic approach and the implementation in teaching maharah kalam at Pondok Modern Darul Hikmah Tulungagung. Pragmatics approach in teaching maharah kalam could be seen or observed in lesson plan which is composed by ustadz. The implementation teaching maharah kalam could be manifested into three main programs at pondok, those are dialogue (al-hiwar), patterned practice (tathbiq al-namudzaj), and spoken composition (tarkib al-syafawi). The result of post-test is higher than the result of pre-test, that is the result of pre-test 60.2 (fair categorized) and the result of posttest 81.3 (good categorized).

This finding tends to support other research which was done by Saefuddin. ${ }^{11}$ Saefuddin found that pragmatics approach in teaching $\mathrm{L} 2$ could contribute the spoken communication ability of L2 learners. All this time, pragmatics approach in teaching L2 could overcome the problems of learning L2. For that reason, it is suggested to the teachers in teaching language by designing the $\mathrm{L} 2$ learning using pragmatics approach. That design of

11 Saefuddin, "Pendekatan Pragmatik Dalam Mendukung Kemampuan Komunikasi Lisan," AlTuras: Mimbar Sejarah, Sastra, Budaya, Dan Agama 19, no. 1 (2013), https://doi.org/10.15408/al-turas.v19i1.3694. teaching should be completed by the function of pragmatics utterances and given examples for each pragmatics function, such as asking, commanding, apologizing, thanking and the others. ${ }^{12}$

The language proficiency could be categorized into two types, those are competence and performance. Competence means that an ability to master language system or the knowledge that enables a person to speak and understand a language, whereas performance means the ability to use a language in communication. In the same meaning, language proficiency could be classified into linguistics competence and communicative competence. The linguistics competence is an ability towards language system, communicative competence is an ability to use the language in any contexts of real communication. Therefore, Purwo states that communicative approach in teaching language is also called as the pragmatic approach. ${ }^{13}$

Pragmatics is a study of language usage in social life. Pragmatics focuses on how society use language to communicate as classical model which is proposed by Austin, Searle, and Grice. This study also is expanded using the newest

\footnotetext{
12 Crandall, "Evaluating Pragmatics-Focused Materials," January 1, 2004.

13 Bambang Kaswanti Purwo, Pragmatik Dan Pengajaran Bahasa: Menyibak Kurikulum 1984 (Yogyakarta: Kanisius, 1990), 130.
} 
approach which is related to sociolinguistics, psycholinguistics and teaching L1 and L2. ${ }^{14}$ Another opinion is conveyed that pragmatics is a study to understand language as a system and its meaning. However, until now this study has not been taught to the language learners. In this case, Levinson has given analysis guidance about the main topics of pragmatics, like deixis, implicature, presupposition, speech act and the structure of conversation. Pragmatics approach could accomplish the problems in semantic analysis. ${ }^{15}$ Besides that, pragmatics approach also understands Grice's cooperative principle, politeness principle, and rhetoric channel similar to ironic and etc. The language meaning can be understood from the intended meaning of the speaker and hearer. In this case, the theory of speech act could be the main reference to understand the meaning of utterances. ${ }^{16}$

Theoretically, empirically, and practically, pragmatics competence in the developing $\mathrm{L} 2$ acquisition has produced some literature in teaching L2. Through big outlining, the

${ }^{14}$ Keith Brown and J. L. Mey, "Pragmatics of Reading," Encyclopedia of Language \& Linguistics, 2006, 51-62, https://doi.org/10.1016/b0-08-044854-2/00387-4.

15 Stephen C. Levinson, Pragmatics (Cambridge: Cambridge University Press, 1983).

16 Jef Verschueren, "Principles of Pragmatics," Journal of Linguistics 21, no. 02 (September 1985):

https://doi.org/10.1017/S0022226700010367. literature could be categorized into two groups; (a) experiment study in any various pragmatics teaching methods and (b) study which is used to dig up the teaching practice to develop pragmatics competence in the L2 classroom. Those both literature could be a reference in teaching $L$ by developing pragmatics competence. "Teaching Pragmatics: Trends and Issues," Annual Review of Applied Linguistics, 2011. ${ }^{17}$

Historically, pragmatics history has two roots of a different approach, those are Europe and American. First, the Anglo-Saxon approach which is sourced from ordinary language philosophy and initiated by Wittgenstein, Austin, and Searle. Second, British approach, contextual and functional. Third, French approach which is based on the enuation theory and elaborated by Emile Benveniste. Fourth, German approach relates to the critical theory's Jürgen Habermas and KarlOtto Apel who examined the pragmatics as part communication theory. This European tradition is rooted from any development of pragmatism philosophy as a new philosophy was born in United States at the end of 19 century and bring

\footnotetext{
${ }^{17}$ Naoko Taguchi, "Teaching Pragmatics: Trends and Issues," Annual Review of Applied Linguistics 31 (March 2011): 289-310, https://doi.org/10.1017/S0267190511000018.
} 
forth syntax, semantics, and pragmatics. $^{18}$

As the reference materials to compose the lesson plan of teaching language using pragmatics approach, the book under a title Handbooks of Pragmatics discusses the basic of pragmatics comprehensively. This book discusses theory, concept and the main topics of pragmatics such as learners approach using language in social context authentically. This book published the author's perspective and critics evaluation towards pragmatics study. ${ }^{19}$ Besides that, Vygotsky's zone of proximal development (ZPD) theory could be used in teaching L2 using pragmatics approach. ZPD is a thought in society or Mind in Society, which is a further psychological process. This article reviewed some research' result about the utilization of ZPD in understanding the development of pragmatic competence and revise teaching $\mathrm{L} 2 .^{20}$

Mastering language does not mean to master phoneme (phonology), words (morphology), and sentence structure (syntax). To master language

18 B. Nerlich, "Pragmatics: History," in Encyclopedia of Language \& Linguistics (Elsevier, 2006), 37-44, https://doi.org/10.1016/B0-08044854-2/00318-7.

19 Anita Fetzer, "Pragmatics as a Linguistic Concept," in Foundations of Pragmatics (Boston: Walter de Gruyter $\mathrm{GmbH}$, 2011).

20 Amy Snyder Ohta, "Pragmatics in Instructed Language Learning," The Encyclopedia of Applied Linguistics 33, no. 3 (2005): 503-17, https://doi.org/10.1002/9781405198431.wbeal088 1. means to understand and use the language based on the context. This is the aim of pragmatics approach in teaching language. This question should be answered, that how the learners are able to conduct speech act such as offerings, asking and apologizing in the right context. In this case, it is needed pragmatics variation knowledge, those are pragmatics which considers area factor, gender, age, ethnic and economic-social classes. Pragmatics variations are intended to answer the question, how do the English, American, Irish speakers offer something? How do men and women apologize? Shortly, pragmatics variation is a study about pragmatics variation in language variation from macro-social perspective. This concept is focused on the speaker's competence to use the language system in social interaction.

Furthermore, language learners also have to know pragmatics variation, that is the different function of language which is influenced by macrosocial function. There are five macrosocial factors which influence pragmatics variation, those are areas, social class, ethnic, gender, and age, but other factors which are supposed to influence the pragmatic variation, are education and religion. ${ }^{21}$

Instead of pragmatics variation, the learners are also necessary to be introduced by using new approaches in

\footnotetext{
${ }^{21}$ Anne Barron, "Variational Pragmatics," in The Routledge Handbook of Pragmatics (London: Routledge, 2017), 91-104.
} 
pragmatics studies which focus on relevance theory. This theory is the development of maxim relevance in Grice's Cooperative principles. This theory sees that a response $(R)$ towards initiation must not be near and explicit. This relevance is seen larger based on communication context. The closer relevance, the easier communication could be understood. On the other hand, the further relevance $\mathrm{R}-1$, the more difficult communication could be understood. In this case, there are two things which can be considered, those are to differentiate the meaning of the utterance and the meaning which is intended by the speaker and understand the meaning based on the context of utterances. $^{22}$

Language and culture have a close relationship because through language society express their culture. Hence, learning a language means that learning culture. Because of that reason, the pragmatic approach also consider the cultural aspect of conducting communication. The different factor of culture usually could arise misunderstanding. The misunderstanding generally is not caused by the intended implicature but mostly it is caused by the inappropriateness of understanding conversation explicature. It is based on the assumption which is established by the relevance theory, that is the

${ }^{22}$ Dan Sperber and Deirde Wilson, "Pragmatics," in Oxford Handbook of Philosophy of Language (Oxford: Oxford University Press, 2005). difference between explicature and implicature. In the interaction of crossculture, one of the parameters which are used to increase misunderstanding is the interlocutor's language competence. The hypothesis is the better of interlocutor's language competence, the higher the probability of misunderstanding happens. Why and wherefores? Because a speaker tends to use their prior culture towards the interlocutor who has a different culture so that it produces the misunderstanding of explicature conversation. Therefore, in order that the communication of cross culture could run well, then the speech participants must have an adequate understanding of cross culture. ${ }^{23}$

\section{Conclusion}

Based on the result of analysis data, the findings can be elaborated as follows.

First, pragmatics approach in teaching maharah kalam at pondok modern Darul Hikmah Tulungagung can be manifested into lesson plan which is composed by ustadz/ teachers.

Second, these lesson plans could be implemented into three main programs of Islamic boarding school or pondok, those are dialogues which are conducted every Sunday morning, (2) patterned practice (tathbiq al-namudzaj) which is conducted every after praying

\footnotetext{
23 Jacques Moeschler, "Intercultural Pragmatics: A Cognitive Approach," Intercultural Pragmatics 1, no. 1 (January 2, 2004), https://doi.org/10.1515/iprg.2004.007.
} 
Isya' and Subuh, and (3) spoken composition (tarkib al-syafawi) which is held every Thursday night after praying Isya'. Thus, pragmatic approach in teaching maharah kalam at Pondok Modern Darul Hiklah could be implemented in various and mutual support programs.

Third, based on the result of pretest and post-test, it was found the difference of the mean of post-test result was higher than the mean of pre-test result. Thus, it can be concluded that the pragmatic approach in teaching maharah kalam at Pondok Modern Darul Hikmah Tulungagung could improve the learners' (santri) Arabic speaking skill.

Based on the findings above, it is suggested that for the Islamic teachers or (ustadz) maharah kalam in order to use the pragmatic approach and implement it into any various programs in order that the aim of teaching maharah kalam could be achieved well.

\section{References}

Annasrullah. A Coordinator of Arabic Teaching. Direct Interview, October 6, 2018.

Arikunto, Suharsimi. Prosedur Penelitian: Suatu Pendekatan Praktik. Jakarta: Rineka Cipta, 2008.

Barron, Anne. "Variational Pragmatics." In The Routledge Handbook of Pragmatics. London: Routledge, 2017.

Brown, Keith, and J. L. Mey. "Pragmatics of Reading." Encyclopedia of
Language \& Linguistics, 2006, 51-62.

https://doi.org/10.1016/b0-08-

044854-2/00387-4.

Crandall, E. "Evaluating PragmaticsFocused Materials." ELT Journal 58, no. 1 (2004): 38-49. https://doi.org/10.1093/elt/58.1.3 8.

Faiq, M. A Teacher of Arabic. Direct Interview, October 6, 2018.

Fetzer, Anita. "Pragmatics as a Linguistic Concept." In Foundations of Pragmatics. Boston: Walter de Gruyter GmbH, 2011.

Kasper, Gabriele. "Introduction: Interlanguage Pragmatics in SLA." Studies in Second Language Acquisition 18, no. 02 (June 1996): 145. https://doi.org/10.1017/S0272263 100014856.

Kathleen, Bardovi-Harlig. "Pragmatics and Language Teaching: Bringing Pragmatice and Pedagogy Together." Pragmatics and Language Learning 7 (1996): 21-39.

Levinson, Stephen C. Pragmatics. Cambridge: Cambridge University Press, 1983.

Mallikarjun, B, Sam Mohanlal, B A Sharada, A R Fatihi, Lakhan Gusain, Jennifer Marie Bayer, S M Ravichandran, G Baskaran, and $L$ Ramamoorthy. "Communicative Language Teaching - A Comprehensive Approach to English Language Teaching" 12, no. 2 (2012): 17. 
Mey, J. L. "Pragmatics of Reading." Encyclopedia of Language \& Linguistics, 2006, 32-38. https://doi.org/10.1016/b0-08044854-2/00387-4.

Miles, Matthew B., and A. Michael Huberman. Qualitative Data Analysis. 3rd ed. London: SAGE, 2014.

Moeschler, Jacques. "Intercultural Pragmatics: A Cognitive Approach." Intercultural Pragmatics 1, no. 1 (January 2, 2004).

https://doi.org/10.1515/iprg.2004. 007.

Nerlich, B. "Pragmatics: History." In Encyclopedia of Language \& Linguistics, 37-44. Elsevier, 2006. https://doi.org/10.1016/B008-044854-2/00318-7.

Ohta, Amy Snyder. "Pragmatics in Instructed Language Learning." The Encyclopedia of Applied Linguistics 33, no. 3 (2005): 50317.

https://doi.org/10.1002/97814051 98431.wbeal0881.

Purwo, Bambang Kaswanti. Pragmatik Dan Pengajaran Bahasa: Menyibak Kurikulum 1984. Yogyakarta: Kanisius, 1990.

Rajagopalan, K. "Social Aspects of Pragmatics." Encyclopedia of Language \& Linguistics, 2006, 434-40.

https://doi.org/10.1016/B0-08-

044854-2/00316-3.

Saefuddin. "Pendekatan Pragmatik Dalam Mendukung Kemampuan Komunikasi Lisan." Al-Turas:
Mimbar Sejarah, Sastra, Budaya, Dan Agama 19, no. 1 (2013). https://doi.org/10.15408/alturas.v19i1.3694.

Sperber, Dan, and Deirde Wilson. "Pragmatics." In Oxford Handbook of Philosophy of Language. Oxford: Oxford University Press, 2005.

Taguchi, Naoko. "Teaching Pragmatics: Trends and Issues." Annual Review of Applied Linguistics, 2011. https://doi.org/10.1017/S0267190 511000018.

Verschueren, Jef. "Principles of Pragmatics." Journal of Linguistics 21, no. 02 (September 1985): 459. https://doi.org/10.1017/S0022226 700010367. 
